\title{
HUBUNGAN DEMOGRAFI DAN PENERAPAN PROTOKOL COVID-19 DENGAN LITERASI KESEHATAN DI KELURAHAN SILABERANTI KOTA PALEMBANG
}

\author{
Ropi'ah $^{1}$, Nur Alam Fajar ${ }^{1}$, Haerawati Idris ${ }^{1}$, Marsidi ${ }^{2}$ \\ ${ }^{1}$ Program Studi Magister Ilmu Kesehatan Masyarakat, Fakultas Kesehatan Masyarakat, Universitas \\ Sriwijaya, Palembang \\ ${ }^{2}$ Program Studi Ilmu Kesehatan Masyarakat, STIK Abdi Nusa, Pangkal Pinang \\ ropiahali@gmail.com ${ }^{1}$; marsidisaid@gmail.com ${ }^{2}$
}

\begin{abstract}
Health Literacy is an effort to increase awareness through the convenience of the public to access of health information. Currently, the implementation of health protocols has not run optimally due to a lack of understanding of public health literacy. The purpose of this study was to determine the relationship between demographics (age, gender, occupation, education, income) and the application of the COVID-19 (3M) protocol with the level of understanding of health literacy in Silaberanti Village, Palembang City. The research method uses quantitative research with a cross-sectional study design with 100 samples. This research was conducted in Silaberanti Village, Palembang City and was carried out from February to April 2021. The results showed that there was a relationship between job and social distancing with understanding of health literacy in Silaberanti Village, Palembang City.
\end{abstract}

Keywords

: Demography, Health Literacy, Health Protocol,

\begin{abstract}
ABSTRAK
Literasi Kesehatan merupakan upaya meningkatkan kesadaran melalui kemudahan masyarakat untuk mengakses informasi tentang kesehatan. Dewasa ini penerapan protokol kesehatan belum berjalan maksimal karena kurangnya pemahaman literasi kesehatan masyarakat. Tujuan dari penelitian ini adalah untuk mengetahui hubungan antara demografi (umur, jenis kelamin, pekerjaan, pendidikan, pendapatan) dan penerapan protokol COVID-19 (3M) dengan tingkat pemahaman literasi kesehatan di Kelurahan Silaberanti Kota Palembang. Metode penelitian menggunakan penelitian kuantitatif dengan rancangan studi potong lintang dengan jumlah sampel sebanyak 100 responden. Penelitian ini dilakukan di Kelurahan Silaberanti Kota Palembang dan dilaksanakan pada bulan Februari sampai dengan April 2021. Hasil penelitian menunjukkan bahwa ada hubungan antara pekerjaan dan menjaga jarak dengan pemahaman literasi kesehatan di Kelurahan Silaberanti Kota Palembang.
\end{abstract}

Kata Kunci : Demografi, Literasi Kesehatan, Protokol Kesehatan,

\section{PENDAHULUAN}

Bulan Desember 2019, WHO China Country Office melaporkan kasus Pneumonia yang tidak diketahui etiologinya di kota Wuhan, Propinsi Hubei, Cina (WHO, 2020). Selanjutnya pada Januari 2020, Cina mengidentifikasi Pneumonia tersebut sebagai jenis baru Virus Corona (Corona virus disease, COVID-19) (Li et al., 2020). Tanggal 30 Januari 2020 WHO telah menetapkan sebagai kedaruratan kesehatan Masyarakat yang meresahkan Dunia (Public Health Emergency of
International Concern (PHEIC)) (WHO, 2020). Penambahan jumlah kasus COVID19 berlangsung cukup cepat dan sudah terjadi penyebaran antar negara bahkan hampir seluruh dunia. Sebuah kejadian yang sangat luar biasa mengguncang dunia kesehatan yang mempengaruhi semua lapisan yang disebabkan oleh Corona Virus (COVID-19). Data 6 Desember 2020 menunjukkan peningkatan yang sangat pesat yang diakibatkan oleh virus Corona mencapai lebih 65 juta terkonfirmasi positif dan lebih dari 1,5 juta orang meninggal dunia. Negara-negara yang paling parah 
dampaknya adalah Amerika Serikat, India dan Brazil, Rusia, Perancis, Inggris, Italia dan Spanyol, sedangkan Indonesia masuk sebagai negara terbanyak ke-21 terkonfirmasi COVID-19 (WHO, 2021).

Ada "infodemik" yang terkait dengan pandemi COVID-19, dimana informasi yang valid dan tidak valid melimpah sehingga diperlukan kemampuan untuk mengakses, memahami, menilai, dan menerapkan informasi kesehatan, menjadikannya penting untuk menavigasi lingkungan informasi COVID-19. Kemampuan tersebut adalah literasi kesehatan (Okan et al., 2020; Abel and McQueen, 2020; Trezona and Jessup, 2020; Cangussu et al., 2020; Paakkari and Okan, 2020; Gautam et al., 2021). Kebingungan tentang informasi COVID-19 secara signifikan lebih tinggi pada mereka yang memiliki tingkat literasi kesehatan yang lebih rendah (Ferguson and Pawlak, 2011; Okan et al., 2020). Selanjutnya dijelaskan bahwa literasi kesehatan menjadi lebih penting dari sebelumnya dalam menghadapi ancaman kesehatan global saat ini, yang berdampak pada hasil di seluruh tingkat model sosio-ekologis (SEM), termasuk perilaku kesehatan individu, hubungan keluarga, perilaku organisasi, pembuatan kebijakan negara, statistik kematian nasional, dan ekonomi internasional.

Okan et al. (2020) menyatakan diperlukan kampanye informasi publik dan promosi literasi kesehatan pada basis populasi untuk navigasi yang lebih baik dari lingkungan informasi selama infodemik, identifikasi disinformasi, dan pengambilan keputusan berdasarkan informasi yang dapat diandalkan dan dapat dipercaya. Haston et al. (2020), Trezona and Jessup (2020) dan Spring (2020) mengatakan salah satu upaya untuk meningkatkan dan mempertahankan kesehatan adalah dengan meningkatkan pengetahuan tentang kesehatan terutama informasi COVID-19 untuk masyarakat, agar terbantu dalam pengambilan keputusan yang tepat tentang kondisi kesehatan mereka.
Literasi kesehatan masih menjadi masalah di semua negara (Lee et al., 2011; Bodur et al., 2017; Broder et al., 2017). Literasi kesehatan dipahami sebagai kemampuan individu untuk menyelesaikan masalah kesehatan yang kompleks dan menilai secara kritis informasi yang tersedia, dapat menjadi cara mempromosikan, meningkatkan, dan mendorong perilaku yang lebih memadai selama krisis seperti COVID saat ini (Okan et al, 2019; 2020, Abel et al., 2020), seperti cara mengakses, memahami, menilai dan menerapkan informasi untuk membuat keputusan dalam hal kesehatan, pencegahan penyakit dan promosi kesehatan. Literasi kesehatan berdampak luas, beberapa peneliti melihat faktor-faktor yang mempengaruhinya. Beberapa penelitian menyatakan adanya hubungan dengan umur, gender, pendidikan, keadaan ekonomi di Turki (Bodur et al., 2017), usia dan tingkat pendidikan di Serbia (JovicVranes et al., 2013), umur, pendidikan dan pendapatan di Taiwan (Lee et al., 2011), umur tua, pendidikan rendah, disparitas etnis, hambatan akses dalam pelayanan kesehatan dan akses informasi kesehatan di Amerika Serikat (Cutilli and Bannet, 2009). Selanjutnya Okan et al. (2019; 2020) menjelaskan kemampuan berpikir untuk memahami informasi kesehatan dipengaruhi oleh umur seseorang. Lebih lanjut Shayakhmetov (2020), menjelaskan bahwa literasi kesehatan dipengaruhi oleh pendidikan dan pekerjaannya. Pendidikan yang baik dapat mempengaruhi pendapatan yang baik pula, dimana dengan mudah menyisihkan sebagian pendapatannya untuk mendapatkan sumber-sumber informasi kesehatan. Hal ini dapat mempengaruhi tingkat kemampuan dalam mengakses, memahami, menilai dan mengaplikasi informasi kesehatan. Lebih lanjut (Nurjanah and Rachmani, 2015; Nutbeam, 2017; Rachmani et al., 2019) menjelaskan informasi dan pendidikan kesehatan dari penyedia layanan kesehatan sebagai media sebagai alat penyebaran informasi kesehatan menjadi akses 
seseorang untuk mendapatkan layanan kesehatan.

Mengubah perilaku di masyarakat dapat dilakukan dengan literasi kesehatan (Sorensen et al., 2012; Sorensen and Brand, 2013; Oo et al., 2015; Okan et al., 2019; 2020; Shi et al., 2020), sehingga literasi kesehatan merupakan variabel penting untuk memberdayakan kesehatan pada individu khususnya dan masyarakat umumnya. Literasi kesehatan telah diakui sebagai salah satu faktor dari variabel kesehatan dan menjadi salah satu tujuan pembangunan kesehatan masyarakat (Nutbeam, 2017; Okan et al., 2019; 2020).

Berdasarkan uraian tersebut, penting untuk melakukan analisis tentang demografi responden dan penerapan protokol kesehatan COVID-19 dengan pemahaman literasi kesehatan. Oleh karena itu, kami mengukur hubungan variabel demografi responden (umur, jenis kelamin, pendidikan, pekerjaan dan pendapatan) dan penerapan protokol kesehatan COVID-19 (kepatuhan pada 3M) dengan literasi ksehatan.

\section{METODE}

Penelitian ini menggunakan jenis penelitian kuantitatif dengan metode analitik observasional dengan rancangan cross sectional study. Data didapat melalui wawancara dengan menggunakan kuesioner (angket penelitian dan HLS-EUSQ10-Indonesia). Populasi penelitian ini adalah seluruh kepala keluarga di kelurahan Silaberanti Kecamatan Jakabaring Kota Palembang berjumlah 4.817 kepala keluarga (kartu keluarga) di Kelurahan Silaberanti (Puskesmas Pembina, 2020). Teknik pengambilan sampel adalah purposive sampling (Bowling and Ebrahim, 2005; Patten and Newhart, 2018; Sugiyono, 2019). Sampel penelitian dihitung dengan menggunakan rumus Slovin, karena rancangan penelitian pontong lintang dan memudahkan dalam mementukan besarnya sampel. Diperoleh sampel sebanyak 97,97 KK, selanjutnya dibulatkan menjadi $100 \mathrm{KK}$, untuk memudahkan dalam perhitungan persentase. Lokasi penelitian berada di wilayah kerja Puskesmas Pembina yaitu dilakukan di Kelurahan Silaberanti Kecamatan Jakabaring Kota Palembang dengan waktu pelaksanaan penelitian dilakukan dari bulan Februari 2021 sampai dengan bulan April 2021. Data yang diperoleh dilakukan analisis univariat (frequency), bivariat (chi square test) dan multivariat (multiple logistics regression) dengan taraf signifikansi sebesar 0,05 (Bowling and Ebrahim, 2005; Ambrosius, 2007; Rosner, 2011; Pagano and Gauvreau, 2018).

\section{HASIL}

Hasil pengolahan data univariat disajikan pada tabel 1. Analisis univariat diperoleh bahwa umur dari responden yang berusia antara 30 sampai dengan 39 tahun adalah terbanyak dengan jumlah 35 orang $(35,0 \%)$, sedangkan yang terendah terdapat di rentang usia diatas 60 tahun sebanyak 6 orang $(6,0 \%)$. Selanjutnya distribusi frekuensi gender yang terbanyak adalah pria dengan jumlah 52 orang $(52,0 \%)$.

\section{Tabel 1. Distribusi Frekuensi Variabel}

\begin{tabular}{crr}
\hline Variabel & n & \% \\
\hline Umur & 13 & 13,0 \\
$20-29$ & & \\
$30-39$ & 35 & 35,0 \\
$40-49$ & 27 & 27,0 \\
$50-59$ & 19 & 19,0 \\
$>=60$ & 6 & 6,0 \\
\hline Gender & & \\
Pria & 52 & 52,0 \\
Wanita & 48 & 48,0 \\
\hline Pendidikan & & \\
SD & 8 & 8,0 \\
SLTP & 14 & 14,0 \\
SLTA & 61 & 61,0 \\
PT & 17 & 17,0 \\
\hline Pekerjaan & & \\
IRT & 28 & 28,0 \\
W Mikro & 8 & 8,0 \\
K.Swasta & 2 & 2,0 \\
PNS & 20 & 20,0 \\
TNI/POLRI & 17 & 18,0 \\
K. BUMN & 25 & 25,0 \\
\hline Pendapatan & & \\
< 1 Juta & 53 & 53,0
\end{tabular}




\begin{tabular}{crr}
1 Jt s/d 3 Jt & 37 & 37,0 \\
3 Jt s/d 5 Jt & 7 & 7,0 \\
$>$. 5 Juta & 3 & 3,0 \\
\hline Memakai Masker & & \\
Sangat Sulit & 0 & 0 \\
Cukup Sulit & 4 & 4,0 \\
Cukup Mudah & 44 & 44,0 \\
Sangat Mudah & 52 & 52,0 \\
\hline Mencuci Tangan & & \\
Sangat Sulit & 0 & 0 \\
Cukup Sulit & 3 & 3,0 \\
Cukup Mudah & 46 & 46,0 \\
Sangat Mudah & 51 & 51,0 \\
\hline Menjaga Jarak & & \\
Sangat Sulit & 4 & 4,0 \\
Cukup Sulit & 14 & 14,0 \\
Cukup Mudah & 43 & 43,0 \\
Sangat Mudah & 39 & 39,0 \\
\hline Literasi Kesehatan & & \\
Sangat Kurang & 1 & 1,0 \\
Kurang & 20 & 20,0 \\
Baik & 57 & 57,0 \\
Sangat Baik & 22 & 22,0 \\
\hline
\end{tabular}

Pendidikan responden yang terbanyak ada pada jenjang pendidikan SLTA dengan jumlah 61 orang $(61,0 \%)$, sedangkan yang terkecil adalah pendidikan SD dengan jumlah sebanyak 8 orang $(8,0 \%)$. Pekerjaan responden yang terbanyak ada pada ibu rumah tangga dengan jumlah sebanyak 28 orang $(28,0 \%)$, sedangkan yang terendah ada pada pekerjaan swasta dengan jumlah 2 orang $(2,0 \%)$.

Selanjutnya untuk pendapatan bulanan pada responden diketahui bahwa responden yang berpenghasilan kurang dari satu juta merupakan jumlah responden yang terbanyak, yaitu 53 orang $(53,0 \%)$, sedangkan jumlah responden yang terendah ada pada pendapatan lebih dari 5 juta, yaitu 3 orang $(3,0 \%)$.

Tabel 2. Hasil Uji Chi Square Variable

\begin{tabular}{|c|c|c|c|c|c|}
\hline \multirow{3}{*}{ Variabel } & \multicolumn{4}{|c|}{ Literasi Kesehatan } & \multirow[t]{3}{*}{ Nilai $\mathrm{P}$} \\
\hline & \multirow{2}{*}{$\begin{array}{c}\text { Kurang } \\
\mathrm{n}\end{array}$} & \multicolumn{3}{|c|}{ Baik } & \\
\hline & & $\%$ & $\mathrm{n}$ & $\%$ & \\
\hline \multicolumn{6}{|l|}{ Umur } \\
\hline Muda & 9 & 18,4 & 40 & 81,6 & \multirow{2}{*}{0,526} \\
\hline Tua & 12 & 23,5 & 39 & 76,5 & \\
\hline \multicolumn{6}{|l|}{ Gender } \\
\hline Pria & 15 & 28,8 & 37 & 71,2 & \multirow{2}{*}{$\mathbf{0 , 0 4 5}$} \\
\hline Wanita & 6 & 12,5 & 42 & 87,5 & \\
\hline \multicolumn{6}{|c|}{ Pendidikan } \\
\hline Rendah & 7 & 33,3 & 14 & 66,7 & \multirow{2}{*}{0,137} \\
\hline Tinggi & 14 & 17,7 & 65 & 82,3 & \\
\hline \multicolumn{6}{|c|}{ Pekerjaan } \\
\hline Kurang & 4 & 11,1 & 32 & 88,9 & \multirow{2}{*}{0,069} \\
\hline Baik & 17 & 26,6 & 47 & 73,4 & \\
\hline \multicolumn{6}{|c|}{ Pendapatan } \\
\hline Rendah & 19 & 21,1 & 71 & 78,9 & \multirow{2}{*}{1,000} \\
\hline Tinggi & 2 & 20,0 & 8 & 80,0 & \\
\hline \multicolumn{6}{|c|}{ Memakai Masker } \\
\hline Kurang & 2 & 66,7 & 1 & 33,3 & \multirow{2}{*}{0,111} \\
\hline Baik & 19 & 19,6 & 78 & 80,4 & \\
\hline \multicolumn{6}{|c|}{ Mencuci Tangan } \\
\hline Kurang & 1 & 33,3 & 2 & 66,7 & \multirow[t]{2}{*}{0,511} \\
\hline Baik & 20 & 20,6 & 77 & 79,4 & \\
\hline \multicolumn{6}{|c|}{ Menjaga Jarak } \\
\hline Kurang & 7 & 41,2 & 10 & 55,6 & \multirow[t]{2}{*}{0,045} \\
\hline Baik & 14 & 16,9 & 69 & 83,1 & \\
\hline
\end{tabular}


Hasil analisis distribusi frekuensi data penerapan protokol kesehatan dissajikan pada tabel 1. Diketahui bahwa responden yang menyatakan menggunakan pemakaian masker dengan sangat mudah sebanyak 52 orang $(52,0 \%)$ dan merupakan jumlah responden terbanyak, sedangkan yang menyatakan cukup sulit sebanyak 4 orang $(4,0 \%)$. Variabel mencuci tangan, responden yang menyatakan melakukan dengan sangat mudah sebanyak 51 orang $(51,0 \%)$ dan merupakan jumlah responden terbanyak dan menyatakan cukup sulit sebanyak 3 orang $(3,0 \%)$. Selanjutnya pada variabel menjaga jarak, responden yang menyatakan melakukan dengan sangat mudah sebanyak 39 orang $(39,0 \%)$ dan merupakan jumlah responden kedua terbanyak dan sangat sulit sebanyak 4 orang $(4,0 \%)$.

Tabel 1 menampilkan hasil analisis distribusi frekuensi dari pemahaman literasi kesehatan pada responden dengan menggunakan kuisioner yang telah terstandar dan dapat digunakan di Indonesia yang bersumber dari artikel Rachmani et al. (2019). Sebanyak 10 pernyataan diberikan untuk mengetahui tingkat pemahaman literasi kesehatan, selanjutnya dibagi atas 4 tingkat. Diketahui bahwa responden dengan tingkat pemahaman sangat kurang sebanyak 1 orang, sedangkan kurang sebanyak 20 orang. Responden yang dengan tingkat pemahaman baik sebanyak 57 orang, dan sangat baik sebanyak 22 orang.

Hasil pengolahan data bivariat disajikan pada tabel 2. Variabel yang berhubungan signifikan dengan literasi kesehatan adalah gender $(\mathrm{p}=0,045)$, menjaga jarak $(p=0,0,045)$. Sedangkan yang tidak berhubungan dengan literasi kesehatan adalah umur $(\mathrm{p}=0,526)$, pendidikan $(\mathrm{p}=0,069)$, pekerjaan $(\mathrm{p}=$ $0,069)$, memakai masker $(\mathrm{p}=0,200)$ dan mencuci tangan $(\mathrm{p}=1,000)$.

Hasil analisis bivariat diperoleh bahwa variabel yang mempunyai nilai $\mathrm{p}<0,25$ adalah jenis kelamin, pendidikan, pekerjaan, memakai masker dan menjaga jarak.
Sehingga dimasukkan ke dalam proses analisis multivariat (Dahlan, 2011). Hasil pengolahan data untuk analisis multivariat disajikan pada tabel 3.

Tabel 3. Hasil Akhir Uji Regresi Logistik (Step 3).

\begin{tabular}{|c|c|c|c|}
\hline-2 Log likelihood & \multicolumn{2}{|c|}{ Nagelkerke R Square } & \\
\hline 90,748 & & & 0,177 \\
\hline \multicolumn{4}{|c|}{ Variables in the Equation } \\
\hline Variables & $B$ & $p$ & OR (IK 95\%) \\
\hline Pendidikan & 0,980 & 0,093 & $2,665(0,849-8,361)$ \\
\hline Pekerjaan & $-1,381$ & $\mathbf{0 , 0 3 4}$ & $0,243(0,066-0,897)$ \\
\hline Menjaga_Jarak & 1,677 & 0,014 & $4,680(1,368-16,010)$ \\
\hline Konstan & $-0,640$ & & \\
\hline
\end{tabular}

Hasil pengujian simultan diperoleh bahwa variabel dependen dapat dijelaskan oleh model sebanyak $17,7 \%$, dan sebanyak $82,3 \%$ di luar model. Selanjutnya analisis multivariat menyatakan bahwa variabel pekerjaan berkorelasi signifikan ( $p$ $<0,05$ ) dengan nilai OR sebesar 0,243. Hal ini menunjukkan bahwa pekerjaan sebagai protektor pada literasi kesehatan. Nilai OR pekerjaan ini dikonversi dengan cara 1 dibagi nilai OR (Dahlan, 2011), diperoleh nilai OR pekerjaan sebesar 4,115. Hasil ini menunjukkan bahwa orang yang mempunyai pekerjaan baik berkemungkinan 4,1 kali mempunyai literasi yang baik dibanding orang mempunyai pekerjaan kurang baik. Selanjutnya variabel menjaga jarak berkorelasi signifikan $(\mathrm{p}<0,05)$ dengan nilai OR sebesar 4,680. Hal ini menunjukkan bahwa menjaga jarak berkontribusi sebanyak 4,7 kali dilakukan oleh orang yang mempunyai literasi kesehatan yang baik.

\section{PEMBAHASAN}

Analisis bivariat diketahui bahwa umur tidak berhubungan siginfikan dengan literasi kesehatan. Hasil ini berbeda dengan Laflamme et al. (2004), Protheroe et al. (2016), Berens and Schaeffer (2019), Joveini et al. (2019), Shi et al. (2020) dan Okan et al. (2019; 2020), dimana 
bertambahnya umur seorang akan mengalami penurunan kemampuan untuk berfikir dan kemampuan sensorisnya, keadaan tersebut dapat mempengaruhi kemampuan membaca dan menangkap informasi, sehingga dapat berpengaruh pada tingkat literasi kesehatan.

Mayoritas masyarakat Kelurahan Silaberanti yang menjadi korban PHK akibat pandemi Covid-19, mereka banyak yang bekerja di sektor informal dan bergantung pada upah harian. Oleh karena itu, mereka tidak mempunyai waktu untuk menambah wawasan dengan membaca buku, koran ataupun menonton TV dikarenakan mobilitas yang tinggi dalam mencari nafkah.

Gender berhubungan signifikan dengan literasi kesehatan. Hasil ini sejalan dengan Protheroe et al. (2016), Davis et al. (2019), Pasha et al. (2019), Shi et al. (2020) dan Okan et al. (2019) dimana karakteristik, peran, tanggungjawab dan atribut antara pria dan wanita yang dibangun secara sosial yang dikenal dengan istilah gender. Joveini, et al. (2019), Okan et al. (2019), Shi et al. (2020) mengemukakan faktor-faktor yang mempengaruhi perbedaan gender dalam hal risiko kesehatan, seperti biologis dan fisiologis, umur harapan hidup, mekanisme perlindungan sosial, norma budaya, kepercayaan religius dan aturan keluarga serta perilaku, pendidikan, pendapatan, dan rendahnya penggunaan pelayanan kesehatan pada wanita.

Penduduk wanita di Kelurahan Silaberanti lebih banyak berinteraksi dengan kader kesehatan maupun sosial masyarakat. Mereka aktif dalam kegiatan sosial seperti mengikuti pelatihan menjadi Tracer Covid, menjadi kader Posyandu, kader Jumantik dan aktif kegiatan PKK sehingga secara langsung mereka akan mudah mengakses informasi kesehatan dari petugas Puskesmas maupun petugas Kelurahan. Selain itu wanita lebih banyak memanfaatkan pelayanan kesehatan seperti Puskesmas untuk berobat maupun memeriksa kehamilan dan imunisasi.
Hasil penenlitian diperoleh bahwa pendidikan tidak berhubungan signifikan dengan literasi kesehatan. Hasil ini berbeda dengan Protheroe et al. (2016), Pasha et al. (2019), Okan et al. (2019), Joveini et al. (2019), Shi et al. (2020) dan Shayakhmetov et al. (2020) dimana pendidikan merupakan suatu upaya pembelajaran pada masyarakat agar masyarakat mau melakukan tindakantindakan (praktik) untuk memelihara dan mengatasi masalah-masalah untuk meningkatkan kesehatannya. Estacio et al. (2020) menjelaskan bahwa selain berdampak pada pembentukan pengetahuan kesehatan, pendidikan juga membentuk keahlian atau kompetensi yang dibutuhkan untuk pembelajaran kesehatan (misalnya kemampuan membaca berbagai sumber informasi kesehatan, kemampuan menggunakan internet). Pernyataan ini dikuatkan oleh Shayakhmetov et al. (2020) bahwa orang dengan berpendidikan rendah dan berpenghasilan rendah memiliki literasi kesehatan yang lebih rendah, dibandingkan responden dengan tingkat pendidikan tinggi dan pendapatan lebih tinggi. Orang dengan literasi kesehatan yang lebih tinggi memiliki tingkat penilaian kesehatan diri yang lebih baik.

Data statistik hasil penelitian didapat kebanyakan responden berpendidikan SLTA. Pendidikan masyarakat yang didominasi dengan SLTA ini berpengaruh terhadap pola pikir dan cara berpikir kritis masyarakat menyikapi suatu masalah atau isu. Daya berpikir kritis tamatan SLTA akan berbeda dengan daya berpikir kritis orang berpendidikan tinggi.

Pekerjaan tidak berhubungan signifikan dengan literasi kesehatan. Hasil ini berbeda dengan Protheroe et al. (2016), Joveini et al. (2019) dan Okan et al. (2019), di mana pekerjaan dapat mempengaruhi kemampuan ekonomi, hal tersebut menentukan seseorang mendapatkan pelayanan kesehatan dan sumber informasi kesehatan.

Data statistik Kelurahan Silaberanti menunjukkan bahwa mayoritas warganya bekerja menjadi buruh dan pedagang. 
Akibat pandemi, sebagian warga yang terdampak PHK mengakibatkan mereka kehilangan pekerjaan tetap mereka. Selama masa-masa tersebut penduduk Silaberanti dituntut untuk terus melakukan mobilitas untuk tidak berdiam diri saja di rumah dan menuntut mereka untuk mencari kerja di luar rumah. Mobilitas masyarakat yang terus bekerja yang menjadi alasan mereka kurang dapat mengakses literasi kesehatan, mereka terus fokus bekerja dan sedikit waktu untuk mengakses literasi kesehatan. Hanya sedikit informasi yang mereka dapatkan dan belum tentu informasi yang akurat dan dapat dipercaya. Keterbatasan ini menjadikan masyarakat kurang dapat memaksimalkan pemahaman mereka berkait literasi kesehatan.

Hasil penelitian diperoleh bahwa pendapatan tidak berhubungan signifikan dengan literasi kesehatan. Hasil ini berbeda dengan Protheroe et al. (2016); Rimnacova et al, (2018), Davis et al. (2019), Pasha et al. (2019), Okan et al. (2019), Shi et al. (2020) dan Shayakhmetov et al. (2020) dimana pendapatan yang rendah akan mempengaruhi tingkat literasi kesehatan yang rendah. Pendapatan dapat mempengaruhi pendidikan dan pelayanan kesehatan, dimana seseorang dengan pendapatan tinggi akan mendapatkan pendidikan yang baik, sehingga mempengaruhi mereka dalam memahami dan menggunakan informasi kesehatan.

Pendapatan masyarakat Kelurahan Silaberanti yang tergolong kecil karena didominasi dengan pekerjaan buruh mengakibatkan sulitnya mendapat pemahaman literasi kesehatan yang bagus. Hal ini membuat masyarakat sulit untuk mengakses informasi yang sifatnya berbayar seperti seminar kesehatan dan literasi kesehatan yang tentu saja ilmu sangat bermanfaat dibandingkan dengan informasi yang didapat secara gratis dan juga informasi yang didapat gratis kurang dapat dipercaya keakuratannya. Sehingga informasi dan pemahaman literasi kesehatan yang didapat masyarakat hanya berkisar pada gosip dan belum tentu benar untuk diterapkan dan dicontohkan oleh para penyuluh kesehatan.

Hasil penelitian menyatakan bahwa memakai masker tidak berhubungan signifikan dengan literasi kesehatan. Hasil ini berbeda dengan Chughtai et al. (2020) dan CDC (2020b; 2021) dimana literasi kesehatan masyarakat sangat diperlukan dalam pencegahan COVID-19, karena perspektif kesehatan masyarakat yang multidisiplin dan multisektoral, dan harus dilakukan dengan partisipasi masyarakat sebagai tanggung jawab bersama, seperti tindakan mitigasi dengan penggunaan masker. Hasil ini perkuat oleh CDC (2020b), Mandal and Das (2020) dan Trezona and Jessup (2020).

Menurut CDC (2020), masker terutama ditujukan untuk mengendalikan sumber virus melalui pengurangan emisi tetesan yang mengandung virus, khususnya pada pengguna yang terinfeksi tanpa gejala atau dengan gejala yang merasa sehat dan mungkin tidak sadar akan penularan mereka kepada orang lain, dan yang diperkirakan bertanggung jawab lebih banyak dari $50 \%$ transmisi. CDC (2020b, 2021) dan Kementerian Kesehatan RI (2020), menjelaskan bahwa masker juga membantu mengurangi penghirupan aerosol ini oleh pemakainya sebagai perlindungan pribadi. Manfaat pencegahan oleh individu meningkat seiring dengan meningkatnya jumlah orang yang menggunakan masker secara konsisten dan benar

Masker jenis kain secara efektif dapat memblokir sebagian besar tetesan besar (yaitu, 20-30 mikron atau lebih besar) dan dapat memblokir tetesan pernafasan dan partikel halus (juga sering disebut aerosol) yang lebih kecil dari 10 mikron; yang meningkat jumlahnya dengan volume tekanan ucapan. Masker kain multi-lapis dapat memblokir hingga $50-70 \%$ dari tetesan dan partikel halus ini, dan membatasi penyebaran kedepan dari yang tidak tertangkap. Masker kain setara dengan masker bedah dalam beberapa penelitian yang dilakukan sebagai 
penghalang untuk pengendalian sumber (CDC, 2020a; Chughtai et al., 2020).

Manfaat pencegahan dengan masker berasal dari kombinasi kontrol sumber dan perlindungan pribadi untuk pemakai masker sebagai kendali sumber dan perlindungan pribadi yang saling melengkapi dan mungkin sinergis, sehingga manfaat individu meningkat dengan penggunaan masker oleh komunitas. Manfaat tambahan jika digabungkan dengan intervensi non-farmasi lainnya seperti jarak jarak, kebersihan tangan, dan ventilasi yang memadai (CDC, 2020b; Chughtai et al., 2020; Mandal and Das, 2020). Sedangkan peneliti lain menyatakan bahwa eksperimen simulasi di udara menunjukkan bahwa masker kapas, masker bedah, dan masker N95 memberikan perlindungan dari transmisi aerosol infektif COVID-19 (CDC, 2020b; CDC, 2021).

Aktivitas masyarakat di Kelurahan Silaberanti yang memiliki kecenderungan untuk memakai masker saat bepergian keluar rumah, di tempat umum maupun di fasilitas lainnya. Masyarakat memiliki kekhawatiran yang tinggi akan adanya pemberitaan COVID-19 mempengaruhi tingkat kepatuhan yang tinggi dalam memakai masker. Ditambah dengan pengaruh lingkungan yang selalu menggunakan masker jika berada di lingkungan sosial menjadikan individu akan merasa malu jika tidak memakai masker.

Hasil penelitian menunjukkan bahwa mencuci tangan tidak berhubungan signifikan dengan literasi kesehatan. Hasil penelitian ini berbeda dengan Haston et al. (2020) dimana literasi kesehatan masyarakat sangat diperlukan dalam pencegahan COVID-19, tindakan mitigasi terhadap penyebaran epidemi, seperti mencuci tangan (Kementerian Kesehatan RI, 2020). Kebersihan tangan sekarang dianggap sebagai salah satu elemen terpenting dari aktivitas pengendalian infeksi (CDC, 2021). Mengingat peningkatan beban infeksi terkait perawatan kesehatan, meningkatnya keparahan penyakit dan kompleksitas pengobatan, diikuti oleh infeksi patogen multi-drug resistant, praktisi perawatan kesehatan mengajak kembali kepada dasar pencegahan infeksi dengan tindakan sederhana seperti kebersihan tangan (CDC, 2021). Selanjutnya dijelaskan bahwa terdapat bukti ilmiah bahwa kebersihan tangan saja dapat secara signifikan mengurangi risiko penularan silang infeksi di fasilitas perawatan kesehatan (CDC, 2021). Kebersihan tangan adalah langkah utama untuk mengurangi infeksi, tetapi kurangnya kepatuhan di antara penyedia layanan kesehatan menjadi masalah di seluruh dunia. Berdasarkan penelitian tentang aspek-aspek yang berpengaruh pada kepatuhan kebersihan tangan dan strategi promosi terbaik, merupakan pendekatan ini terbukti efektif (CDC, 2021). Manfaat tambahan jika digabungkan dengan intervensi non-farmasi lainnya seperti jarak jarak dan ventilasi yang memadai (CDC, 2020a; Chughtai et al., 2020; Mandal and Das, 2020).

Hasil pengamatan di lokasi penelitian menunjukkan bahwa kebiasaan mencuci tangan sudah sering dilakukan masyarakat dalam aktivitas sehari - hari seperti memasak, mencuci, maupun ketika melakukan ibadah. Selain itu, di tempat tempat umum juga sudah disediakan sarana mencuci tangan, seperti di pasar, fasilitas umum maupun ditempat wisata, tetapi masyarakat masih kurang kesadaran mencuci tangan.

Hasil penelitian diperoleh bahwa menjaga jarak berhubungan signifikan dengan literasi kesehatan. Hasil ini sejalan Newbold et al. (2020), Bourassa, et al. (2020) dan Spring (2020) dimana literasi kesehatan masyarakat sangat diperlukan dalam pencegahan COVID-19, tindakan mitigasi terhadap penyebaran epidemi dengan menjaga jarak (social distancing). Lebih lanjut Spring (2020), Kementerian Kesehatan RI (2020) dan Newbold et al. (2020) menyatakan pentingnya respons masyarakat dan peran penting literasi 
kesehatan dalam menyelamatkan nyawa selama darurat kesehatan global.

Menjaga jarak adalah alat penting untuk mengendalikan penyebaran penyakit, terutama jika tidak ada perawatan dan vaksin. Tindakan menjaga jarak dapat melindungi kesehatan masyarakat dari tertular dan menyebarkan COVID-19 (CDC, 2020b; 2021). Oleh karena itu, menjaga jarak adalah salah satu cara terbaik yang kita miliki untuk menghindari terpapar virus ini dan memperlambat penyebarannya di masyarakat. Pentingnya menjaga jarak setidaknya 6 kaki (2 meter) dari orang lain untuk memperlambat penyebaran COVID19, pada saat pergi ke tempat umum (CDC, 2020b). Manfaat tambahan jika digabungkan dengan intervensi non-farmasi lainnya seperti kebersihan tangan, dan ventilasi yang memadai (CDC, 2020a; Chughtai et al., 2020; Mandal and Das, 2020).

Aktivitas masyarakat di Kelurahan Silaberanti masih banyak yang belum melakukan perilaku menjaga jarak, dimana masih ditemukannya masyarakat yang selalu berkumpul di tempat - tempat umum seperti pasar dan posyandu. Padahal sudah sering dihimbau oleh petugas baik dari Puskesmas maupun lintas sektor yang terkait untuk tetap menjaga jarak namun sepertinya hal itu tetap tidak dilaksanakan oleh masyarakat dikarenakan aktivitas yang tinggi dan mobilitas yang padat. Ditambah dengan diberlakukannya new normal maka kegiatan yang mengundang kerumunan masyarakat, misalnya acara hajatan dan nikahan di kampung tidak dapat dicegah sehingga protokol kesehatan terutama menjaga jarak sudah tidak diberlakukan lagi.

Hasil analisis multivariat diperoleh bahwa pekerjaan dan menjaga jarak berkorelasi signifikan terhadap literasi kesehatan.

Pekerjaan dapat mempengaruhi kemampuan ekonomi, hal tersebut menentukan seseorang dalam mendapatkan pelayanan kesehatan dan mendapatkan sumber informasi kesehatan (Okan et al.
(2019). Hasil ini sejalan dengan Joveini et al. (2019), bahwa pegawai negeri sipil, pelajar, dan wiraswasta memiliki tingkat literasi kesehatan yang lebih tinggi daripada individu yang menganggur, ibu rumah tangga, dan pensiunan.

Menjaga jarak berhubungan signifikan dengan literasi kesehatan. Hasil ini sejalan Sorensen et al (2020) dan Spring (2020) dimana literasi kesehatan masyarakat sangat diperlukan dalam pencegahan COVID-19, tindakan mitigasi terhadap penyebaran epidemi dengan menjaga jarak (social distancing). Spring (2020) dan ECDC (2020) menyatakan pentingnya respons masyarakat dan peran penting literasi kesehatan dalam menyelamatkan nyawa selama darurat kesehatan global.

Menjaga jarak adalah alat penting untuk mengendalikan penyebaran penyakit, terutama jika tidak ada perawatan dan vaksin. Tindakan menjaga jarak dapat melindungi kesehatan masyarakat. dari tertular dan menyebarkan COVID-19 (CDC, 2020a). Oleh karena itu, menjaga jarak adalah salah satu cara terbaik untuk menghindari terpapar virus ini dan memperlambat penyebarannya di komunitas. Pentingnya menjaga jarak setidaknya 6 kaki (2 meter) dari orang lain saat pergi ke tempat umum (CDC, 2020a; CDC, 2021). Manfaat tambahan jika digabungkan dengan intervensi seperti kebersihan tangan, dan ventilasi ruangan yang memadai (CDC, 2020a; Chughtai et al., 2020; Mandal and Das, 2020).

\section{KESIMPULAN}

Hasil uji bivariat diperoleh bahwa literasi kesehatan berhubungan signifikan dengan gender dan menjaga jarak, sedangkan yang tidak berhubungan signifikan adalah umur, pendidikan, pekerjaan, pendapatan, memakai masker dan mencuci tangan. Sedangkan hasil uji multivariat diperoleh bahwa literasi kesehatan berkorelasi signifikan dengan pekerjaan dan menjaga jarak. 


\section{UCPAN TERIMAKASIH}

Terimakasih peneliti ucapkan kepada semua pihak yang mendukung sehingga penelitian in dapat berjalan.

\section{DAFTAR PUSTAKA}

Abel, T. and McQueen, D., (2020). Critical health literacy and the COVID-19 crisis. Health Promotion International. 1-2. doi: 10.1093/heapro/daaa040.

Ambrosius, W.T., (2007). Topics in Biostatistics. New Jersey: Human Press.

Bodur, A.S., Filiz E. and Kalkan, I., (2017). Factors Affecting Health Literacy in Adults: A Community Based Study in Konya, Turkey. International Journal of Caring Sciences. 10(1) : 100-109.

Bourassa, K.J., Sbarra, D.A., Caspi, A. and Moffitt, T.E., (2020). Social Distancing as a Health Behavior: County-Level Movement in the United States During the COVID-19 Pandemic Is Associated with Conventional Health Behaviors. Ann. Behav. Med. 54: 548-556. DOI: 10.1093/abm/kaaa049.

Bowling, A. and Ebrahim, S., (2005). Handbook of Health Research Methods: Investigation, measurement and analysis. New York: Open University Press.

Broder, J., Okan, O., Bauer, U., Bruland, D., Schlupp, S., Bollweg, T.M., et al., (2017). Health literacy in childhood and youth: a systematic review of definitions and models. BMC Public Health. 17:361. 25pp. DOI 10.1186/s12889-017-4267-y.

Cangussu, L.R., de Barros, I.R.P., Filho, C.A.L.B, Filho, J.D.R.S, Lopes, M.R. (2020). COVID-19 and health literacy: the yell of a silent epidemic amidst the pandemic. Rev Assoc Med Bras. 66(SUPPL 2):31-33.

CDC, (2020). COVID 19. social distancing. https://www.cdc.gov/coronavirus/201 9-ncov/prevent-getting-sick/socialdistancing.html. Disitasi tanggal 2 Maret 2021.

CDC, (2020). Scientific Brief: Community Use of Cloth Masks to Control the Spread of SARS-CoV-2. https://www.cdc.gov/coronavirus/201 9-ncov/more/masking-science-sarscov2.html. Disitasi tanggal 2 Maret 2021.

CDC, (2021). How to protect yourself and others.

https://www.cdc.gov/coronavirus/201 9-ncov/more/ How to protect yourself and others.html. Disitasi tanggal 12 Juni 2021.

Chughtai, A.A., Seale, H. and Macintyre, C.R., (2020). Effectiveness of Cloth Masks for Protection Against Severe Acute Respiratory Syndrome Coronavirus 2. Emerging Infectious Diseases. 26(10). e1-e5. doi.org/10.3201/eid2610.200948.

Cutilli, C.C. and Bennett, I.M., (2009). Understanding the Health Literacy of America Results of the National Assessment of Adult Literacy. Orthop Nurs. 28(1): 27-34. doi:10.1097/01.NOR.0000345852.22 122.d6.

Dahlan, M.S., (2011). Statistik untuk Kedokteran dan Kesehatan. Jakarta: Salemba Empat.

Davis, S.N., Wischhusen, J.W., Sutton, S.K., Christy, S.M., Chavarria, E.A., Sutter, M.E., et al., (2019). Demographic and psychosocial factors associated with limited health literacy in a community-based sample of older Black Americans. Patient Education and Counseling. $\mathrm{xxx}$ (2019) $\mathrm{xxx}-\mathrm{xxx}$. doi.org/10.1016/j.pec.2019.08.026.

ECDC, (2020). Considerations relating to social distancing measures in response to COVID-19 - second update. Stockholm : European Centre for Disease Prevention and Control. 
Estacio, E.V., Whittle, R. and Protheroe, J., (2017). The digital divide: Examining socio-demographic factors associated with health literacy, access and use of internet to seek health information. Journal of Health Psychology. 1-8. https://doi.org/10.1177/13591053176 95.

Ferguson, L.A. and Pawlak, R., (2011). Health Literacy: The Road to Improved Health Outcomes. The Journal for Nurse Practitioners. pp 123-129.

doi:10.1016/j.nurpra.2010.11.020.

Gautam, V., Dileepan, S, Rustagi, N., Mittal, A., Patel, M., Shafi, S., et al., (2021). Health literacy, preventive COVID 19 behaviour and adherence to chronic disease treatment during lockdown among patients registered at primary health facility in urban Jodhpur, Rajasthan. Diabetes \& Metabolic Syndrome: Clinical Research \& Reviews. 15: 205-211. https://doi.org/10.1016/j.dsx.2020.12. 023.

Haston, J.C., Miller, G.F., Berendes, D., Andújar, A., Marshall, B., Cope, J., et al., (2020). Characteristics Associated with Adults Remembering to Wash Hands in Multiple Situations Before and During the COVID-19 Pandemic - United States, October 2019 and June 2020. Morbidity and Mortality Weekly Report. 69(40): 1443-1449.

Jovic-Vranes, A., Bjegovic-Mikanovic, V., Marinkovic, J. and Kocev, N., 2013. Health literacy in a population of primary health-care patients in Belgrade, Serbia. Int J Public Health. DOI 10.1007/s00038-010-0181-0.

Joveini, H., Rohban, A., Askarian, P., Maheri, M. and Hashemian, M., (2019). Health literacy and its associated demographic factors in 18-65-yearold, literate adults in Bardaskan, Iran. $J$ Edu Health Promot. 8(244).
Kementerian Kesehatan RI, (2020). Pedoman Pencegahan dan Pengendalian Coronavirus Disease (COVID-19). Jakarta: Kementerian Kesehatan RI.

Lee, H.Y., Lee, J., and Kim, N.K., (2017). Gender Differences in Health Literacy Among Korean Adults: Do Women Have a Higher Level of Health Literacy Than Men?. American Journal of Men's Health. 9(5): 370-379. DOI: $10.1177 / 1557988314545485$.

Li, Q., Guan, X., Wu, P., Wang, X., Zhou, L., Tong, Y. and Ren, R., (2020). Early Transmission Dynamics in Wuhan, China, of Novel Coronavirus-Infected Pneumonia. $N$ Engl J Med. 382:1199-207. DOI: 10.1056/NEJMoa2001316.

Mandal, A.and Das, K., (2020). COVID-19 Pandemic: I Cloth Mask Really Protect Public FromSARS-CoV-2? (The way of handling to get Results). International Journal of Innovative Science and Research Technology. 5(5): 521-525.

Nurjanah and Rachmani, E., (2015). Health Literacy in Semarang City, Indonesia. Demography and Social Deteminant of Health Literacy. Faculty of Health Sciences. Semarang: Dian Nuswantoro University, Indonesia.

Newbold, S.C., Finnoff, D., Thunström, L., Ashworth, M. and Shogren, J.F., (2020). Effects of Physical Distancing to Control COVID-19 on Public Health, the Economy, and the Environment. Environmental and Resource Economics. 76:705-729. https://doi.org/10.1007/s10640-02000440-1.

Nutbeam, D., (2017). Health literacy as a population strategy for health promotion. JJHEP. 25(3): 210-222.

Okan, O. Bollweg, T.M., Berens, E-M., Hurrelmann, K., Bauer, U. and Schaeffer, D., (2020). CoronavirusRelated Health Literacy: A CrossSectional Study in Adults during the 
COVID-19 Infodemic in Germany. Int. J. Environ. Res. Public Health. 17(5503). doi:10.3390/ijerph17155503.

Okan, O., Bauer, U., Levin-Zamir, D., Pinheiro, P. and Sorensen, K., (2019). International Handbook of Health Literacy: Research, Practice and Policy Across the Lifespan. Bristol : Policy Press.

Oo, W.M., Soe, P.P. and Lwin, K.T., (2015). Status and determinants of health literacy: a study among adult population in selected areas of Myanmar. Int J Community Med Public Health. 2(3):318-322. DOI: http://dx.doi.org/10.18203/2394$6040 . i j c m p h 20150489$.

Paakkari, L. and Okan, O., (2020). COVID19: health literacy is an underestimated problem. thelancet public-health. 5: e249-e250. https://doi.org/10.1016/S24682667(20)30086-4.

Pagano, M. and Gauvreau, K., (2018). Principles of Biostatistics. Boca Raton: CRC Press.

Pasha, F., Dreshaj, D., Ismaili, A., Sopjani, I., Brooke, J., Dreshaj S., (2019). Health literacy assessment of primary care patients in Low and Middle Income Countries. bioRxiv. https://doi.org/10.1101/630533.

Patten, M.L. and Newhart, M., (2018). Understanding Research Methods: An Overview of the Essentials. New York: Taylor \& Francis.

Protheroe, J., Whittle, R., Bartlam, B., Estacio, E.V., Linda Clark, L. and Kurth, J., (2016). Health literacy, associated lifestyle and demographic factors in adult population of an English city: a cross-sectional survey. Health Expectations. 20: 112-119. doi: $10.1111 /$ hex.12440.

Puskesmas Pembina, (2020). Pasien terkonfirmasi positif COVID-19. Palembang: Puskesmas Pembina.

Rachmani, E., Hsu, C-Y., Nurjanah, N., Chang, P.W., Shidik, G.F.,
Noersasongko, E., et al., (2019). Developing an Indonesia's health literacy short-form survey questionnaire (HLS-EU-SQ10-IDN) using the feature selection and genetic algorithm. Computer Methods and Programs in Biomedicine. 182(105047).

https://doi.org/10.1016/j.cmpb.2019.1 05047.

Rimnacova, Z., Kajanova, A. and Brizona, B., (2018). Selected Socio-Economic Factors of Health Literacy of the Poor. Human Affairs. 28: 461-470. DOI: 10.1515/humaff-2018-0037.

Roosner, B., (2011). Fundamentals of Biostatistics. Boston: Brooks/Cole.

Shayakhmetov, S.S., Toguzbayeva, K.K., Ismailova, A.A., Tabibi, R., Derbishalieva, Z.K. and Dzhusupov, K.O., (2020). Health Literacy of Rural Population of Kazakhstan. Iran J Public Health. 49(7):1269-1277.

Shi, J., Qi, L., Li, Y. and Liu, X., (2020). Investigation of Health Literacy Status in Beijing, China. Health Literacy Research and Practice. 4(3):e174-e184. doi:10.3928/24748307-20200731-01.

Sorensen, K., Okan, O., Kondilis, B. and Levin-Zamir, D., (2020). Rebranding social distancing to physical distancing: calling for a change in the health promotion vocabulary to enhance clear communication during a pandemic. Global Health Promotion. 1757-9759; 0(0): 1-10; 986126.

DOI:10.1177/1757975920986126.

Sorensen, K., Van den Broucke, S., Fullam, J., Doyle, G., Pelikan, J., Slonska, Z. and Brand, H., (2012). Health literacy and public health: A systematic review and integration of definitions and models. BMC Public Health. 12(80).

Sorensen, K. and Brand, H., (2013). Health literacy lost in translations? Introducing the European Health 
Literacy Glossary. Health Promotion International.

doi:10.1093/heapro/dat013.

Spring, H., (2020). Health literacy and COVID-19. Health Information \& Libraries Journal. DOI: 10.1111/hir.12322.

Sugiyono, 2019. Metode Penelitian Kuantitatif Kualitatif dan $R \& D$. Bandung: CV Alfabeta.

Trezona, A. and Jessup, R., (2020). Health Literacy in the COVID-19 Pandemic: Understanding the health literacy of health service users in Northern Metropolitan Melbourne. Melbourne: Northern Health.

WHO, (2021). COVID-19 Weekly Epidemiological Update. Edition 44, published 15 June 2021.

WHO, (2020). Coronavirus disease (COVID-19) pandemic. https://www.euro.who.int/en/healthtopics/healthemergencies/coronavirus-covid19/news/news/2020. Disitasi 5 Januari 2021. 